\title{
COMPARATIVE ANALYSIS BETWEEN TWO-TIER BOARDS AND UNITARY BOARDS IN THE CASE OF THE COMPANIES LISTED ON THE BUCHAREST STOCK EXCHANGE
}

\author{
Bogdan Aurelian MIHAIL ${ }^{a *}$, Dalina DUMITRESCU ${ }^{b}$ \\ ${ }^{a, b}$ Bucharest University of Economic Studies, Romania
}

\begin{abstract}
This paper examines the role of two-tier boards versus one-tier board systems for the case of firms listed on the Bucharest Stock Exchange (BSE). The literature shows that one-tier or unitary and twotier or dualistic board systems have different advantages and disadvantages, like lower levels of information problems in unitary systems and higher levels of independence in the case of two-tier systems. The purpose of this paper is to collect information on various board and firm characteristics from around 60 companies with the unitary system and 6 companies with the dual system listed on $B S E$ and analyses the differences that impact their financial performance. The results indicate that companies with a two-tier system are larger and have larger board sizes. In addition, they have better performance on average, measured by the return on equity indicator. However, the regression results indicate that these positive performance effects of the two-tier board become statistically insignificant when the various board and company characteristics are included as control variables. The low sample size of the two-tier board companies is a possible factor creating statistically insignificant results. The additional regressions results show that when the share of independent board members increases by $10 \%$, the ROE increases by $1.26 \%$.
\end{abstract}

KEYWORDS: Corporate Governance, Firm Performance, Board of Directors, Two-Tier Boards, One-Tier Boards, Return on Equity, Romania.

\section{INTRODUCTION}

The board of directors plays an important role in the governance of companies (Brown, 2015). The growing sizes of firms and the complexity of efficient management creates the need of the separation of ownership and management in modern corporations (Milosevic, et al., 2015). Then, owners or shareholders can hire professional executives to manage the company on their behalf. While this separation allows the professional management of companies, it can also create new challenges like the principal-agency problems (Tirole, 2010). In this case, the managers of companies (i.e., the agents) can work to maximise their returns and interests, even if they imply costs to the shareholders (i.e., the principal). The corporate governance approach tries to develop measures and policies to address these agency problems. In this context, one of the most effective institutions is the board of directors (Davies, 2000). The board tries to supervise the actions and strategies of the managers so that they are in line with the interests of shareholders. Given the importance of the boards, there are many regulations, studies, and reports that aim to understand the mechanisms and consequences of effective regulation and supervision by boards. The present paper focuses on the unitary versus twotier system (of the one-tier versus two-tier nature) of the board of directors.

\footnotetext{
${ }^{*}$ Corresponding author.E-mail address: bog.mihail@gmail.com
} 
The one-tier or unitary board structure is generally associated with the Anglo-Saxon or the US-style corporate governance, whereas the two-tier or dualistic board structure is usually associated with the German-style corporate governance (Bainbridge, 2015).

This point is stated by Block and Gerstner (2016) as follows: "The "Anglo-American" model of a one-tier board structure is largely a reflection of the neoliberal norms of shareholder primacy and free-market capitalism. The German two-tier model is in many ways a reflection of stakeholder primacy, codetermination and managerialism" (p. 2). The unitary boards have a focus on shareholders and independence, whereas the dual boards have a focus on stakeholders. However, there has also been some convergence between these board types as the unitary boards started to include different committees that function as a new tier in the system. Then, examining how these two board structures matter in terms of various company characteristics and whether they affect the company performance becomes an important research endeavour. The present paper examines these two questions in the case of the companies listed on the Bucharest Stock Exchange, Romania. The plan of the paper is as follows. The next section gives the problem statement, while the third section provides the research questions and the aims. Then, the fourth section presents the research methods. The empirical results are presented in the fifth section. Finally, the sixth section concludes the paper.

\section{PROBLEM STATEMENT}

The board of directors plays crucial roles in the supervision and monitoring of the executives, as well as guiding the long-term business strategies and vision of corporations. Then, the structure of the boards can be an important factor for the competitiveness and performance of companies. In this context, unitary versus dualistic or one-tier versus two-tier system stands out as an important research area within the corporate governance literature. There are many studies that examine the importance of the unitary-dualistic board systems in different settings. For example, De Moor (2014) states that one-tier boards can be more integrated, and function more smoothly compared to the two-tier boards. In addition, one-tier boards can have lower levels of imperfect information. However, two-tier boards can have more diverse board members, specialisation in their tasks, and higher levels of independence compared to unitary boards. Hence, there seem to be both advantages and disadvantages associated with each board structure. Then, comparing these benefits and costs becomes a question of empirical analysis. For example, Belot et al. (2014) examine the case of French companies and find that "Companies with severe asymmetric information tend to opt for unitary boards; companies with a potential for private benefits extraction tend to adopt two-tier boards" (p. 364). In addition, they show that two-tier board systems provide more effective monitoring. In another study, Chang and Lin (2017) examine the case of Taiwan which allowed companies to switch from two-tier to unitary board systems on a voluntary basis. The authors note that there were no major effects of the board system on the corporate governance characteristics and processes of countries.

Overall, there is a limited number of studies in the literature that examine the differences between unitary and two-tier board systems in terms of corporate governance and firm performance dimensions. The present paper aims to contribute to the relevant literature by examining this problem in the context of the companies listed on the Bucharest Stock Exchange.

\section{RESEARCH QUESTIONS AND AIMS OF THE RESEARCH}

Based on the above discussions, there are two research questions that the present paper examines. The first question is given as follows "How do board and firm characteristics differ between companies with unitary and two-tier systems?". Then, the second question is presented as follows: "Does the two-tier board system has a better company performance after controlling for the relevant company and board characteristics?". To answer these research questions, the paper collects information on various board and company characteristics of the companies listed on the Bucharest 
Stock Exchange. Then, the research aims to display the differences in these characteristics between unitary and two-tier board systems. In addition, the paper aims to display any differential effect of the board system on company performance.

\section{RESEARCH METHODS}

The paper uses standard research methods that are consistent with the studies in the literature and the present study utilise a linear regression model to check if the dual system has any effect on company performance. For example, it presents the main board characteristics such as board size, the share of independent and women board members, the share of non-executive board members, and the $\mathrm{CEO} /$ President duality are compared across the two board systems. In the literature, linear regression models are used commonly to examine the effects of different board characteristics on firm performance (Klein, 1998) (Rose, 2005) (Francis, et al., 2012). In this context, the relevant regression model used in the analysis is presented as follows:

$$
\begin{aligned}
& \text { ROE }_{i}=\beta_{0}+\beta_{1} \text { Dual }_{i}+\beta_{2} \text { Size }_{i}+\beta_{3} \text { BoardSize }_{i}+\beta_{4} \text { ShareIndepBoardMembers }_{i}+ \\
& \beta_{4} \text { Dual } * \text { ShareIndepBoardMembers } \\
& +
\end{aligned}
$$

The above equation is estimated as a cross-section since the relevant company-level data are collected for the most recent period. The dependent variable is chosen as the return on equity (ROE) consistent with the studies in the relevant literature. Then, the dummy variable of Dual takes a value of 1 if the corresponding firm has a two-tier board system and 0 otherwise. The company size (measured by turnover) and the board size (i.e., the number of members in boards) are used as the other independent variables. In the literature, there are many studies that show the importance of independent board members for company performance (Fuzi, et al., 2016) (Shan, 2019). Then, the above regression model also includes the share of independent board members as an additional independent variable. In addition, to see whether this effect differs for the board system, the regression model includes an interaction term between the two-tier board system and the share of independent board members. The regression model is estimated using the OLS method with clustered errors (Wooldridge, 2016). The next section presents the results of these empirical methods in the context of the companies listed on the Bucharest Stock Exchange.

\section{FINDINGS}

The section presents the findings of the empirical analysis. The results are presented in two parts. The first part presents the summary statistics and correlation analysis. Then, the second part presents the findings of the regression analysis.

\subsection{Summary statistics and correlation analysis}

The differences between the two-tier and unitary board systems are first examined in terms of summary statistics.

Table 1 presents the summary statistics in the case of both unitary and two-tier boards, the main variables used in the comparison are: ROE, firm size, board size, the share of independent board members, the share of non-executive board members, the share of woman presence in the board, existence, or non-existence of President/CEO duality and if the CEO is a woman or not.

It is seen from Table 1 there are around 60 companies with unitary board systems, whereas the number of companies with two-tier board systems is very limited, with just 6 observations, due to the very limited number of companies from both categories listed on BSE. The low sample size in the case of the two-tier board system becomes an important research limitation for the empirical analysis as getting statistically significant results could be difficult. 
Table 1 shows that firms with a two-tier board system have better firm performance measured by the ROE and higher board sizes. They are also larger.

Table 1. Summary statistics

\begin{tabular}{|c|c|c|c|c|c|}
\hline \multicolumn{6}{|c|}{ Summary Statistics - Firms with Unitary Boards } \\
\hline Variable & Obs & Mean & Std.Dev. & Min & Max \\
\hline $\mathrm{ROE}$ & 64 & 8.1 & 14.1 & -23.6 & 71.3 \\
\hline Firm Size & 64 & $709,000.000$ & $2,050,000.000$ & 185,000 & $14,800,000.000$ \\
\hline Board Size & 69 & 4.971 & 1.74 & 1 & 11 \\
\hline $\begin{array}{l}\text { Independent } \\
\text { Share }\end{array}$ & 58 & 37.016 & 29.16 & 0 & 100 \\
\hline $\begin{array}{c}\text { Non-Executive } \\
\text { Share }\end{array}$ & 66 & 73.384 & 22.611 & 0 & 100 \\
\hline Women Share & 67 & 20.771 & 23.316 & 0 & 100 \\
\hline CEO Duality & 64 & 0.297 & 0.46 & 0 & 1 \\
\hline CEO Women & 66 & 0.106 & 0.31 & 0 & 1 \\
\hline \multicolumn{6}{|c|}{ Summary Statistics - Firms with Two-Tier Boards } \\
\hline Variable & Obs & Mean & Std.Dev. & Min & Max \\
\hline ROE & 6 & 27.8 & 32.6 & 1 & 76 \\
\hline Firm Size & 6 & $3,810,000.000$ & $7,880,000.000$ & $26,900.000$ & $19,800,000.000$ \\
\hline Board Size & 6 & 5.667 & 2.422 & 3 & 9 \\
\hline $\begin{array}{l}\text { Independent } \\
\text { Share }\end{array}$ & 6 & 10.317 & 16.053 & 0 & 33.33 \\
\hline $\begin{array}{c}\text { Non-Executive } \\
\text { Share }\end{array}$ & 6 & 23.333 & 40.825 & 0 & 100 \\
\hline Women Share & 6 & 8.1 & 12.84 & 0 & 28.6 \\
\hline CEO Duality & 6 & 0 & 0 & 0 & 0 \\
\hline CEO Women & 6 & 0.333 & 0.516 & 0 & 1 \\
\hline
\end{tabular}

Source: Author's own research

Table 2 shows the correlations among the relevant variables. In the case of the unitary board system, ROE has a positive and statistically significant correlation with the share of independent board members. Other correlations of ROE are not statistically significant. In the case of the two-tier board systems, ROE has positive correlations with board size and the shares of non-executive, independent, and women board members. However, none of these correlations is statistically significant, with the low sample size being a major possible factor in this result.

The below results showed that there is a big difference in the ROE averages between unitary and twotier systems. This difference can also be presented graphically. Figure 1 shows the box plots of the ROE variable for two cases. It is seen that the unitary system has a distribution of ROE that is lower compared to the distribution in the two-tier system case. As another finding, it is found in Table 2 that there is a positive correlation between ROE and the share of independent board members. This relationship is also presented graphically in Figure 2. The graph shows the scatter plot of these variables, along with a linear fit line. The positive slope of the fit line confirms the positive association between firm performance and the share of independent board members. Overall, this part shows some important differences between the unitary and two-tier board systems in the case of the companies listed on the Bucharest Stock Exchange. 
Table 2. Cross correlations

\begin{tabular}{|c|c|c|c|c|c|c|c|c|}
\hline Unitary Boards & (1) & (2) & (3) & (4) & (5) & (6) & (7) & (8) \\
\hline (1) ROE & 1 & & & & & & & \\
\hline (2) size & -0.165 & 1 & & & & & & \\
\hline (3) board_size & 0.045 & 0.242 & 1 & & & & & \\
\hline (4) indep_share & $0.268 *$ & -0.003 & -0.039 & 1 & & & & \\
\hline (5) non_exec_share & 0.078 & 0.165 & $0.302 *$ & $0.491 *$ & 1 & & & \\
\hline (6) women_share & -0.099 & -0.15 & -0.139 & -0.115 & -0.067 & 1 & & \\
\hline (7) ceo_duality & -0.074 & -0.184 & -0.109 & $-0.327 *$ & $-0.417^{*}$ & -0.067 & 1 & \\
\hline (8) ceo_women & -0.012 & -0.097 & -0.133 & 0.195 & 0.033 & 0.22 & -0.118 & 1 \\
\hline Dual Boards & $(1)$ & (2) & (3) & (4) & $(5)$ & (6) & (7) & (8) \\
\hline (1) $\mathrm{ROE}$ & 1 & & & & & & & \\
\hline (2) size & 0.475 & 1 & & & & & & \\
\hline (3) board_size & 0.372 & 0.728 & 1 & & & & & \\
\hline (4) indep_share & 0.285 & 0.695 & 0.767 & 1 & & & & \\
\hline (5) non_exec_share & 0.037 & -0.326 & -0.593 & -0.441 & 1 & & & \\
\hline (6) women_share & 0.121 & -0.232 & 0.159 & -0.487 & -0.127 & 1 & & \\
\hline (7) ceo_duality & . & & & & & & ${ }^{\circ}$ & \\
\hline (8) ceo_women & 0.087 & 0.601 & 0.107 & 0.306 & -0.443 & -0.489 & & 1 \\
\hline
\end{tabular}

* shows significance at the 0.05 level

Source: Author's own research

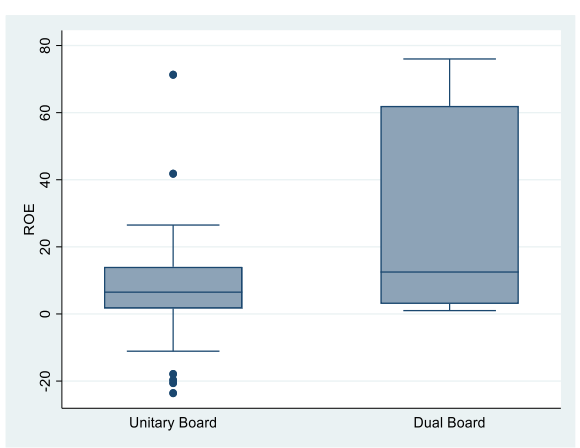

Figure 1. Box Plot of ROE

Source: Author's own projections

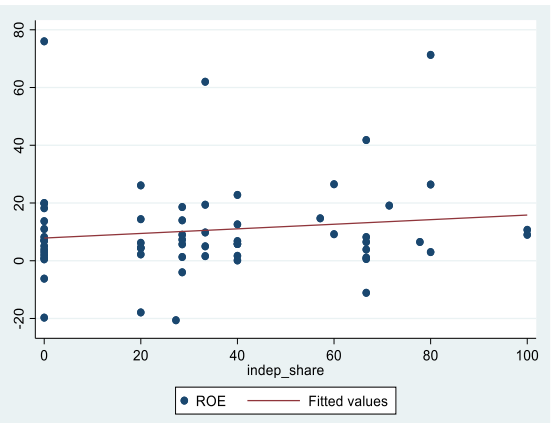

Figure 2. Scatter Plot of ROE and Independent Member Share

Source: Author's own projections

\subsection{Regression analysis}

The regression model is estimated using the OLS method with clustered errors. Table 3 presents the relevant results. It is seen that there is a total of 53 observations in the regression model due to some missing observations for firms. 6 of this sample are the companies with two-tier board systems. The regression coefficients show that company size and board size are positively associated with the company performance indicator of ROE. However, the regression coefficients are not statistically significant at the $5 \%$ level.

Table 3 shows that the regression coefficient of the two-tier system is also positive, indicating that the two-tier system has a better company performance on average after controlling for the board and 
company characteristics. However, the corresponding regression coefficient is not statistically significant. In contrast to these statistically insignificant results, Table 3 shows that the share of independent board members is positive and statistically significant at the 5\% level. The coefficient of 0.126 implies that when the share of independent board members increases by $10 \%$, the ROE increases by $1.26 \%$. This number can be considered an important economic effect on the company performance.

Table 3. OLS regression results

\begin{tabular}{|c|c|c|c|c|c|c|c|}
\hline ROE & Coef. & $\begin{array}{l}\text { St. } \\
\text { Err. }\end{array}$ & $\begin{array}{l}\text { t- } \\
\text { value }\end{array}$ & $\begin{array}{l}\text { p- } \\
\text { value }\end{array}$ & $\begin{array}{l}{[95 \%} \\
\text { Conf }\end{array}$ & Int.] & Sig \\
\hline Size & 0 & 0 & 0.02 & 0.985 & 0 & 0 & \\
\hline Board_size & 0.234 & 2.052 & 0.11 & 0.913 & -4.8 & 5.256 & \\
\hline Dual & 19.247 & 18.07 & 1.06 & 0.328 & -25 & 63.465 & \\
\hline Indep_share & 0.126 & 0.038 & 3.31 & 0.016 & 0.03 & 0.218 & $* *$ \\
\hline Indep_dual & 0.447 & 0.467 & 0.96 & 0.375 & -0.7 & 1.59 & \\
\hline Non_exec_share & 0.03 & 0.108 & 0.28 & 0.791 & -0.2 & 0.294 & \\
\hline Women_share & 0 & 0.058 & -0.01 & 0.996 & -0.1 & 0.141 & \\
\hline Constant & 0.537 & 8.658 & 0.06 & 0.953 & -21 & 21.722 & \\
\hline Mean dependent var & 11.028 & & \multicolumn{3}{|c|}{ SD dependent var } & 18.421 & \\
\hline R-squared & 0.177 & & \multicolumn{3}{|c|}{ Number of obs. } & 53 & \\
\hline F-test & . & & \multicolumn{3}{|c|}{ Prob > F } & . & \\
\hline Akaike crit. (AIC) & 459.898 & & \multicolumn{3}{|c|}{ Bayesian crit. (BIC) } & 471.72 & \\
\hline
\end{tabular}

$* * * \mathrm{p}<0.01, * * \mathrm{p}<0.05, * \mathrm{p}<0.1$

Source: Author's own research

The regression results show that the interaction term between the two-tier system and share of independent members is positive, implying stronger performance effects in the case of the two-tier board systems. However, the regression coefficient for the interaction term is not also statistically significant. Overall, these results display some positive effects of the two-tier system on company performance, whereas the corresponding effects are statistically significant. As discussed above, the low sample size for the companies with two-tier board systems can be a major factor in the statistical insignificance of the results.

\section{CONCLUSIONS}

This paper has examined the role of the two-tier versus unitary board systems in the case of the companies listed on the Bucharest Stock Exchange. It collects information about board and company characteristics in the case of around 60 companies with unitary system boards and 6 companies with two-tier board systems, due to the very limited number of companies from both categories listed on BSE. The literature finds that both systems can have their own advantages and disadvantages. The empirical analysis shows that, in the case of the companies listed on the Bucharest Stock Exchange, the companies with a two-tier board system are larger in terms of revenues and have larger board 
sizes on average. In addition, the two-tier board companies have larger unconditional ROE levels, indicating superior performance on average. However, when a linear regression model is estimated, it is found that the positive effects of the two-tier board system become statistically insignificant after controlling for various board and company characteristics. The results also show the positive effects of the independent board members on the company performance and imply that the presence of independent board members on the boards would be useful to improve corporate governance quality and firm performance in Romania.

\section{REFERENCES}

Bainbridge, S. M. (2015). The board of directors. The Oxford Handbook of Corporate Law and Governance.

Belot, F., Ginglinger, E., Slovin, M. B., \& Sushca, M. E. (2014). Freedom of choice between unitary and two-tier boards: An empirical analysis. Journal of Financial Economics, 112(3), pp. 364385.

Block, D., \& Gerstner, A. M. (2016). One-Tier vs. Two-Tier Board Structure: A Comparison Between the United States and Germany. The university of Pennsylvania. Comparative Corporate Governance and Financial Regulation. Seminar Papers.

Brown, J. R. (2015). The demystification of the board of directors. Am. Bus. LJ, 52,131.

Chang, H., \& Lin, L. (2017). From Double Board to Unitary Board System: Independent Directors and Corporate Governance Reform in Taiwan. In. Independent Directors in Asia: A Historical, Contextual and Comparative Approach: Dan W. Puchniak, Harald Baum \& Luke Nottage eds. Cambridge University Press.

Davies, P. L. (2000). The board of directors: composition, structure, duties and powers. Paper on Company Law Reform in OECD Countries: A Comparative Outlook of Current Trends.

De Moor, C. (2014). Board effectiveness: one-tier versus two-tier boards. Board Effectivenness: OneTier versus Two-Tier Boards, 67.

Francis, B. B., Hasan, I., \& Wu, Q. (2012). Do corporate boards affect firm performance? New evidence from the financial crisis. New evidence from the financial crisis (April 12,2012). Bank of Findland Research Discussion Paper, (11).

Fuzi, S. F. S., Halim, S. A. A., \& Julizaerma, M. K. (2016). Board independence and firm performance. Procedia Economics and Finance, Volume 37, pp. 460-465.

Klein, A. (1998). Firm performance and board commitee structure. The Journal of Law and Economics, 41(1), pp. 275-304.

Milosevic, D., Andrei, S., \& Vishny, R. W. (2015). A survey of corporategovernance. The journal of finance, Volume 52, pp. 737-783.

Rose, C. (2005). The composition of semi-two-tier corporate boards and firm performance. Corporate Governance: An International Review, 13(5), pp. 691-701.

Shan, Y. G. (2019). Managerial ownership, board independence and firm performance. Accounting Research Journal.

Tirole, J. (2010). The theory of corporate finance. Princetown University Press.

Wooldridge, J. M. (2016). Introductory econometrics: A modern approach. Nelson Education. 